\title{
FINANCIAL SHOCKS AND EXCHANGE MARKET PRESSURE
}

Ila Patnaik and Madhavi Pundit

\section{NO. 581}

May 2019
ADB ECONOMICS WORKING PAPER SERIES 


\section{Financial Shocks and Exchange Market Pressure}

Ila Patnaik and Madhavi Pundit

No. 581 | May 2019
Ila Patnaik (ilapatnaik@gmail.com) is a professor at the National Institute of Public Finance and Policy, Delhi. Madhavi Pundit (mpundit@adb.org) is an economist at the Economic Research and Regional Cooperation Department, Asian Development Bank. 
(C) 2019 Asian Development Bank 6 ADB Avenue, Mandaluyong City, 1550 Metro Manila, Philippines

Tel +632632 4444; Fax +6326362444

www.adb.org

Some rights reserved. Published in 2019.

ISSN 2313-6537 (print), 2313-6545 (electronic)

Publication Stock No. WPS190161-2

DOI: http://dx.doi.org/10.22617/WPS190161-2

The views expressed in this publication are those of the authors and do not necessarily reflect the views and policies of the Asian Development Bank (ADB) or its Board of Governors or the governments they represent.

ADB does not guarantee the accuracy of the data included in this publication and accepts no responsibility for any consequence of their use. The mention of specific companies or products of manufacturers does not imply that they are endorsed or recommended by ADB in preference to others of a similar nature that are not mentioned.

By making any designation of or reference to a particular territory or geographic area, or by using the term "country" in this document, $A D B$ does not intend to make any judgments as to the legal or other status of any territory or area.

This work is available under the Creative Commons Attribution 3.0 IGO license (CC BY 3.0 IGO)

https://creativecommons.org/licenses/by/3.o/igo/. By using the content of this publication, you agree to be bound by the terms of this license. For attribution, translations, adaptations, and permissions, please read the provisions and terms of use at https://www.adb.org/terms-use\#openaccess.

This CC license does not apply to non-ADB copyright materials in this publication. If the material is attributed to another source, please contact the copyright owner or publisher of that source for permission to reproduce it. $\mathrm{ADB}$ cannot be held liable for any claims that arise as a result of your use of the material.

Please contact pubsmarketing@adb.org if you have questions or comments with respect to content, or if you wish to obtain copyright permission for your intended use that does not fall within these terms, or for permission to use the ADB logo.

Corrigenda to ADB publications may be found at http://www.adb.org/publications/corrigenda.

Notes:

In this publication, "\$” refers to United States dollars.

ADB recognizes "China" as the People's Republic of China.

The ADB Economics Working Paper Series presents data, information, and/or findings from ongoing research and studies to encourage exchange of ideas and to elicit comment and feedback about development issues in Asia and the Pacific. Since papers in this series are intended for quick and easy dissemination, the content may or may not be fully edited and may later be modified for final publication. 


\section{CONTENTS}

TABLES AND FIGURES

ABSTRACT

$\begin{array}{ll}\text { I. INTRODUCTION } & 1\end{array}$

II. MOTIVATION AND QUESTIONS

III. $\quad$ DATA AND METHODOLOGY 8

A. Data 8

B. Methodology 9

$\begin{array}{ll}\text { IV. } & 10\end{array}$

A. Determinants of Exchange Rate Changes 10

B. Determinants of Exchange Market Pressure 12

V. ROBUSTNESS CHECKS $\quad 17$

A. $\quad$ Alternative Measures of Exchange Rate Regimes 17

B. Determinants of Exchange Market Pressure during Appreciation Pressures 18

C. Alternative Exchange Market Pressure Measures 18

$\begin{array}{lll}\text { VI. CONCLUSION } & 21\end{array}$

$\begin{array}{ll}\text { APPENDIX } & 23\end{array}$

$\begin{array}{lr}\text { REFERENCES } & 27\end{array}$ 


\section{TABLES AND FIGURES}

\section{TABLES}

$1 \quad$ Regression Results for Exchange Rate Changes 11

2 Exchange Market Pressure Regression Results 13

3 Regression Results for Exchange Market Pressure Standardized Coefficients 15

4 Regression Results for Exchange Market Pressure Robust Coefficients 16

$5 \quad$ Alternative Measures of Exchange Rate Regimes Robust Coefficients 17

6 Regression Results for Quantitative Easing (Period 1) Robust Coefficients 19

7 Regression Results for Exchange Market Pressure Robust Coefficients 20

8 Summary Statistics $\quad 21$

\section{FIGURES}

$1 \quad$ United States 10-Year Treasury Bill Rates, January-November 2013

2 Movements in Nominal Exchange Rates by Region, 2010-2018 2

3 Foreign Exchange Reserves by Region, 2000-2015 3

4 Mean Exchange Market Pressure by Region, 2010-2018 5

5 Median Exchange Market Pressure by Region, 2010-2018 6 


\begin{abstract}
The taper tantrum episode induced a sudden outflow of capital from emerging markets back to the United States. This paper analyzes exchange market pressure in 93 developing and emerging market economies during this episode, drawing on recent methodological improvements in measuring exchange market pressure. We find that all economies in the sample that were integrated with global capital markets were heavily hit. Although popular discourse suggested that the extent of an economy's fragility depended on its macroeconomic fundamentals, we find these fundamentals did not have much of a role in determining the level of pressure on a currency.
\end{abstract}

Keywords: capital flows, exchange market pressure, financial shock, international trade and finance, macroeconomics, taper tantrum

JEL codes: E52, F31, F32 


\section{INTRODUCTION}

The Federal Reserve responded to the financial crisis after Lehman Brothers' bankruptcy by lowering interest rates to the zero lower bound (at or below $0.25 \%$ ) and expanding liquidity. This was accompanied by unconventional monetary policy in the form of balance sheet expansion (or quantitative easing) by buying financial assets, thereby boosting money supply in the financial system and stimulating economic growth. These low interest rates affected emerging markets in the search for yield by global asset managers. Strong capital inflows to these markets ensued, causing emerging market currencies to appreciate.

The United States (US) economy recovered slowly in the first half of 2013, growing $1.7 \%$ in the second quarter of that year. As growth was expected to be higher in the following quarters, the Federal Reserve announced its intention to reduce or wind down qualitative easing at the May 1 Federal Open Market Committee meeting. With the release of this meeting's minutes and the testimony to Congress of then Federal Reserve Chair Ben Bernanke on May 22, the markets understood that the Federal Reserve would start tightening monetary policy by tapering quantitative easing (a period referred to widely as the taper tantrum).

Figure 1: United States 10-Year Treasury Bill Rates, January-November 2013

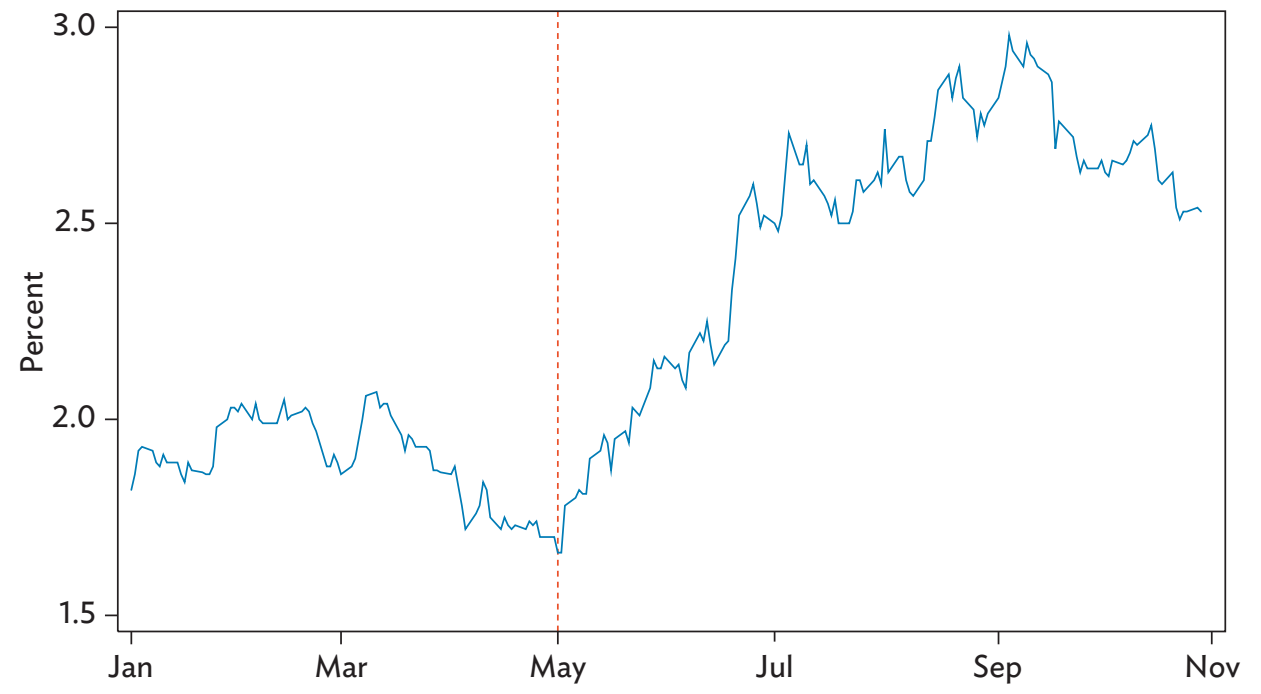

Note: The dashed line is the taper tantrum in May 2013.

Source: Federal Reserve Economic Data (accessed 1 August 2018).

Despite the signaling that quantitative easing will be tapered, markets expected a rapid tightening in US monetary policy. The announcement triggered a drastic response in the US 10-year Treasury bill rate (Figure 1). In the months before May, markets had been expecting an extended soft interest rate scenario, at a time when the long rate was declining. After the first quantitative easing announcement in November 2008, developing and emerging market currencies underwent a mild appreciation, though they had been appreciating for some time since 2006 (except for a brief period from 2008 to 2009). In response to the taper announcement, however, the 10-year rate rose by 125 
basis points in 4 months. This triggered large capital flows out of emerging economies in all regions, resulting in a sharp depreciation.

Central banks responded to the exchange market pressure during the taper tantrum through four main channels: (i) allowing freer movement of exchange rates, $\Delta e_{i}$; (ii) intervening in foreign exchange markets, $I_{t}$; (iii) changing domestic interest rates, $\Delta\left(i_{t}-i^{*}\right)$; and (iv) imposing capital controls. In response to the global financial crisis, most countries had built up their foreign exchange reserves. Immediately after the taper tantrum, several countries sold their reserves to defend their currencies, while others allowed freer currency movements with limited intervention, as shown in Figures 2 and 3.

Figure 2: Movements in Nominal Exchange Rates by Region, 2010-2018
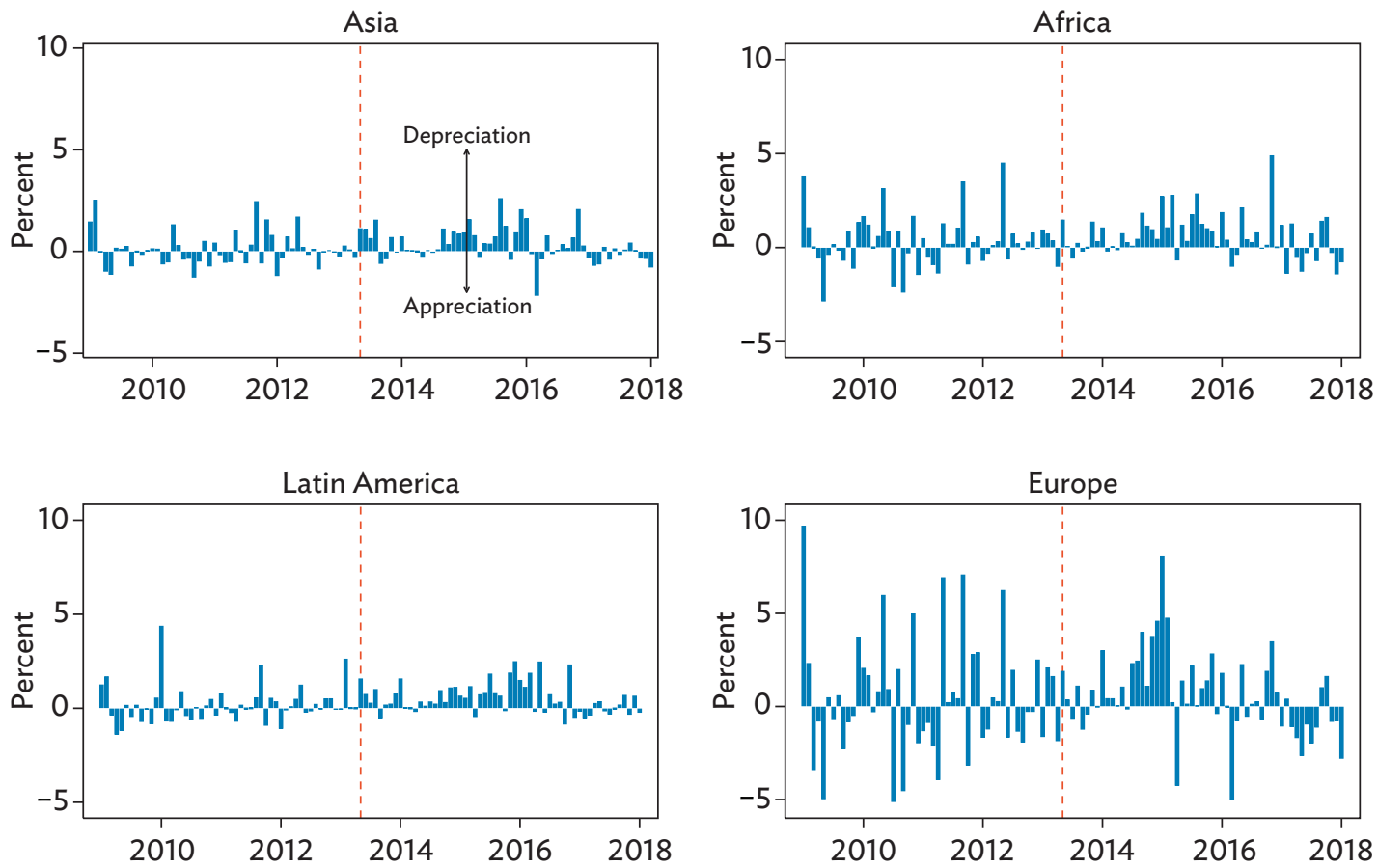

Notes: The dashed line is the taper tantrum in May 2013. Green line is the taper tantrum in May 2013. Regional numbers were computed as the average of percentage changes in nominal exchange rates of component countries. Component countries include developing and emerging economies based on the International Monetary Fund's classification. The Appendix lists the economies in the regional groupings.

Source: CEIC Data Company (accessed 2 May 2018).

This episode had a differential impact across developing and emerging market economies, with some currencies facing sharper depreciation and stronger bouts of volatility. Exchange rate movements, however, do not always reflect the actual pressure on a market, since policy makers can respond by intervening with foreign exchange reserves and interest rate changes.

Patnaik, Felman, and Shah (2017) developed a new measure for exchange market pressure with consistent units: percentage change in the exchange rate. This permits cross-country and acrosstime comparisons. This measure adds the observed change in the exchange rate with the change that would have been expected to have occurred had there been no intervention. Their key formula for 
exchange market pressure, $E M P$ is: $E M P_{t}=\Delta e_{t}+\rho_{t} * I_{t}$, where $\Delta e_{t}$ is the percentage change in the exchange rate; $I_{t}$ is the intervention measured in billion US dollars; and $\rho_{t}$ is the conversion factor, which is the change in the exchange rate associated with $\$ 1$ billion of intervention. The value of the conversion factor depends on the size and liquidity of the foreign exchange market.

In this paper, we use the cross-country monthly dataset from Patnaik, Felman, and Shah (2017) to evaluate the heterogeneity in exchange market pressure experienced across developing and emerging economies during the taper tantrum. We use a cross-sectional ordinary least squares regression to understand the possible determinants of this pressure. For the analysis, we consider macroeconomic fundamentals, including fiscal deficit, inflation, gross public debt, and current account balance; size of the financial economy and its exposure to external shocks; interest rate differentials; capital account openness; and exchange rate regimes. The coefficients are estimated with robust standard errors.

We report the standardized coefficients to understand the relative importance of the statistically significant variables. Estimates of standardized regression give an estimate of the increase in standard deviation of the dependent variable given a 1-standard deviation increase in the independent variable. This allows for assessing the relative strength of the independent variables in the system, which is not affected by the choice of units to measure the variables. This is followed by checks to evaluate whether our analysis is robust to alternative measures of exchange market pressure and classification schemes of exchange rate regimes.

Figure 3: Foreign Exchange Reserves by Region, 2000-2015
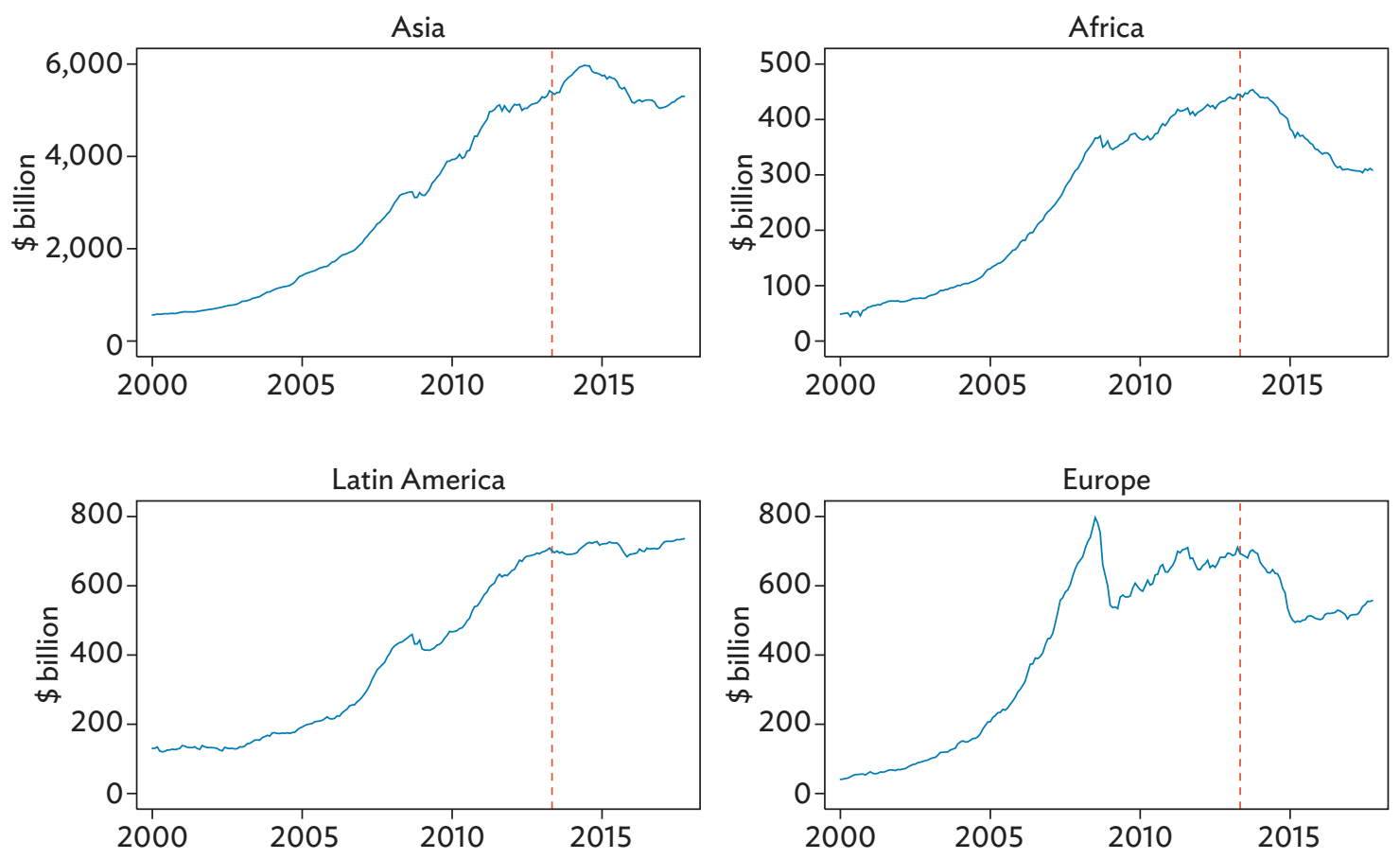

Notes: The dashed line is the taper tantrum in May 2013. Regional numbers were computed as the average of percentage changes in nominal exchange rates of component countries. Component countries include developing and emerging economies based on the International Monetary Fund's classification. The Appendix lists the economies in the regional groupings.

Source: CEIC Data Company (accessed 2 May 2018). 
We analyze whether the determinants of exchange market pressure during the taper tantrum are different from the factors determining this pressure after an appreciation shock following the start of quantitative easing in 2009.

As a first step, we evaluate the determinants of nominal exchange rate movements across various developing and emerging economies. We find the exchange rate regime is significant in explaining heterogeneous exchange rate movements. Countries with an intermediate or managed exchange rate regime experienced a significantly sharper depreciation than a hard-peg currency. Similarly, economies with a higher level of private external financing (total private inflows in equities, bonds, and debt) experienced sharper depreciation. But greater capital account openness, to an extent, absorbed these depreciation shocks.

Since evaluating the determinants of exchange rate movements does not encompass the complete dynamics of an economy's exchange market performance, we estimate the determinants of exchange market pressure during the taper tantrum across the same set of countries. For variables that significantly affected both exchange rate movements and exchange market pressure, the estimated effect was found to be much stronger for the latter.

Similar to our results for exchange rate movements, we observe the importance of capital account openness in making an economy more resilient to exchange market pressure generated by currency shocks during the taper tantrum. We do not find macroeconomic fundamentals to be significant. But variables that determine the vulnerability of the real and financial economy to external shocks, such as trade openness and extent of external private financing, are important determinants of stronger depreciation pressures in certain emerging and developing economies. Standardized coefficients bring out the relatively greater role that private external financing played in intensifying the depreciation pressure on economies, even though capital account openness absorbed depreciation pressure to some extent.

Emerging markets, as shown in the $\mathrm{MSCl}$ index, experienced sharper depreciation and stronger exchange market or depreciation pressures, reflecting portfolio rebalancing effects. In closing, we find a significant impact of exchange rate regimes in determining heterogeneity in the extent of exchange market pressure in developing and emerging economies.

\section{MOTIVATION AND QUESTIONS}

The 10-year US Treasury bill rate hit a low of 1.37\% in 2016 and has risen since then to approach 2.91\% in December 2018, comparable to the levels reached after the taper tantrum. US interest rate increases, accompanied by a strengthening US dollar led to a sell-off in emerging market currencies, which recently experienced a sharp depreciation. The exchange rate performance of emerging market economies from May to October 2018 is reminiscent of the taper tantrum in 2013, with certain currencies performing much worse than others, despite many economies drastically improving their fundamentals in the past 5 years. 
Figure 4: Mean Exchange Market Pressure by Region, 2010-2018
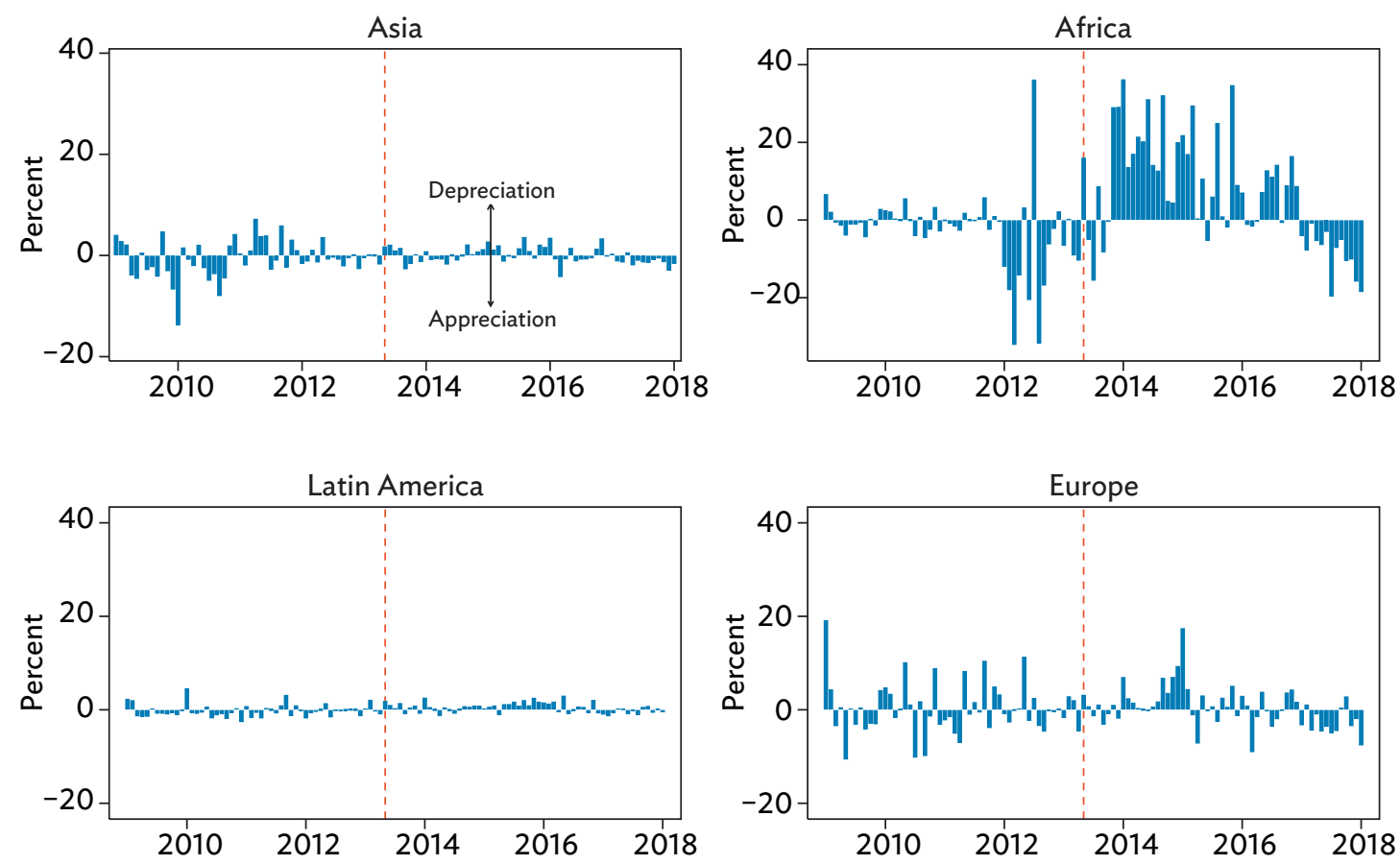

Notes: The dashed line is the taper tantrum in May 2013. Regional numbers computed as the mean of the exchange market pressure of component countries. Component countries include developing and emerging economies based on the International Monetary Fund's classification. The Appendix lists the economies in the regional groupings.

Source: Authors' calculation using data from Patnaik, Ila, Joshua Felman, and Ajay Shah. 2017. "An Exchange Market Pressure Measure for Cross-Country Analysis.” Journal of International Money and Finance 73 (Part A): 62-77.

The mean and median exchange market pressure experienced by emerging economies across all regions during the taper tantrum is given in Figures 4 and 5, respectively. It is evident that after the taper announcement all emerging economies experienced strong depreciation pressures, but these pressures were stronger in some countries than others. This is in contrast with the period after the first Federal Reserve quantitative easing, known as the QE-1 announcement, on November 2008 when, after some lag, emerging economies experienced appreciation pressures when asset purchases expanded.

The size of the depreciation pressure after the taper announcement varied significantly across regions. The impact was heavier in Africa than in emerging and developing economies in other regions. Variations within regions were also wide, as some economies experienced higher depreciation pressure than others. This puts the focus on the determinants of the differential impact of financial shocks across developing and emerging market economies, and what these economies needed to do to absorb the depreciation pressures generated by global financial shocks.

The literature on the impact of financial shocks is rich, but there is considerable heterogeneity in the outcome variables studied and in the possible transmission channels or determinants of a currency's performance in response to a global financial shock. Some studies assess the impact of crises on exchange rate movements, capital flows, and yield curves. The impact of financial shocks on 
exchange market pressure and the determinants of the impact of heterogeneity over time and regions have been also been evaluated (Frankel and Saravelos 2012; Aizenman and Hutchison 2012; Aizenman and Binici 2016; Feldkircher, Horvath, and Rusnak 2014). Traditional measures of exchange market pressure have been used for the analysis of individual countries. Most analyses studying the impact of financial shocks suffer from the problems of ad hoc choices for exchange market pressure index weights and crisis thresholds. The construct of traditional indices for exchange market pressure is such that they are normalized, allowing for comparison across different periods for the same country. But they are not suitable for cross-country comparisons, especially during financial shocks.

Research on the impact of global financial shocks on international capital flows has considered a variety of push-pull factors; that is, global financial conditions versus domestic macroeconomic and financial conditions. Cross-country analyses focus mainly on different pull factors; for example, macroeconomic fundamentals, characteristics of the financial sector, and institutional factors. Transmission mechanisms, such as portfolio balance and liquidity channels, have also been studied to understand the structural linkages between unconventional monetary policy and capital flows to emerging economies (Lim, Mohapatra, and Stocker 2014).

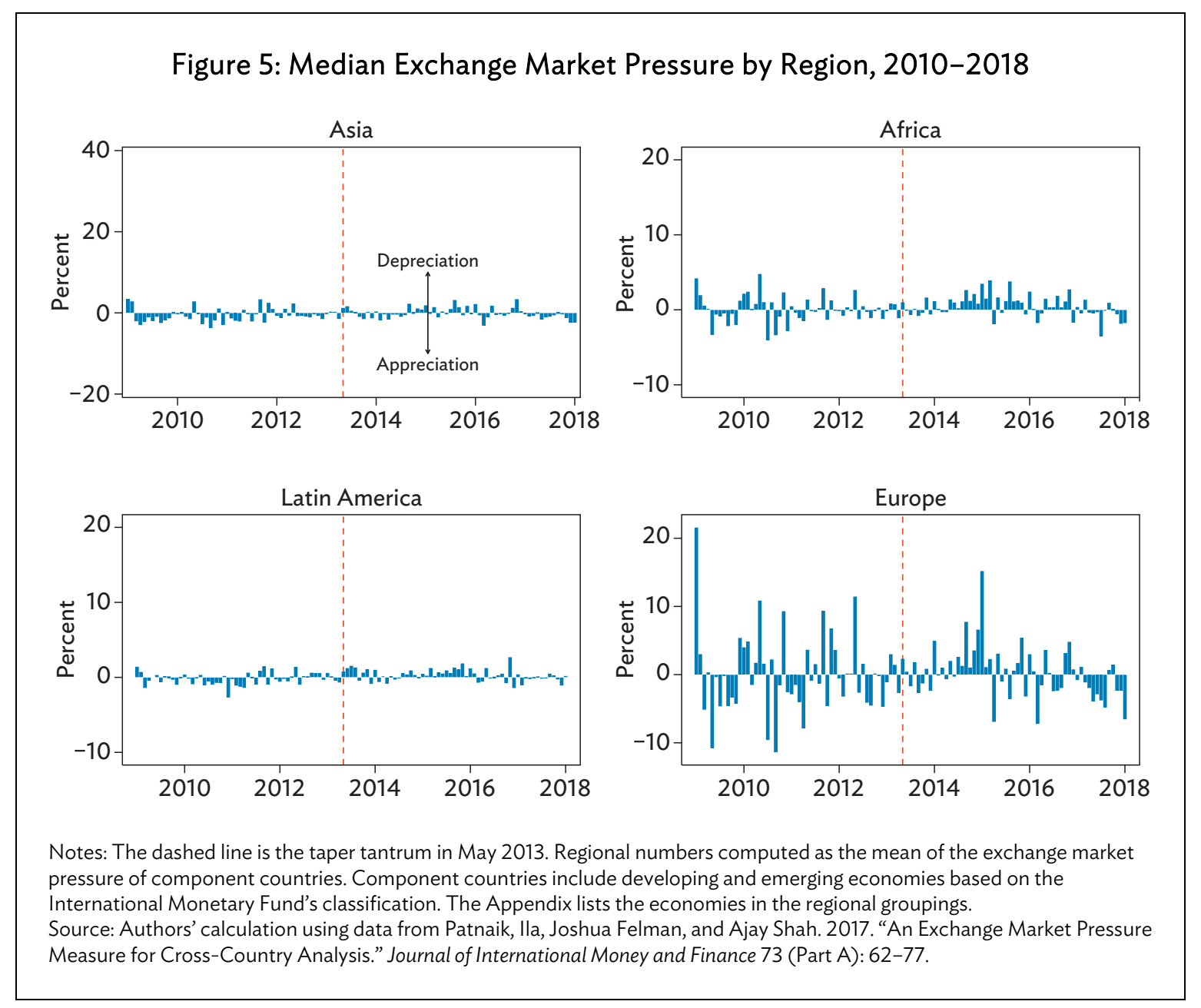


Frankel and Saravelos (2012) discuss the leading indicators useful for assessing the extent of a country's vulnerability during a crisis, looking at multiple local pull factors. This work was followed by many cross-country analyses on the importance of macroeconomic fundamentals in relation to domestic financial factors for exchange market performance during a financial shock.

Evidence on the role of different factors in determining exchange market performance is mixed in the literature. Some studies show that economies with better macroeconomic fundamentals, such as lower past credit growth, larger current account surpluses and saving rates, and lower short-term external debt, suffered less from the performance of exchange markets during a depreciation shock (Frankel and Saravelos 2012; Ahmed, Coulibaly, and Zlate 2017).

Other studies do not agree with this view. They find little evidence for the influence of macroeconomic fundamentals on the reaction of exchange rates, foreign reserves, and stock prices to global shocks - and show instead that the size of a financial market is the most important determinant of a differential impact. These studies relate this to the vulnerabilities posed by total liabilities, large gross financial exposures, and short-term financial flows during liquidity crises (Aizenman and Hutchison 2012, Eichengreen and Gupta 2015).

Another strand of the literature focuses on the importance of country-specific institutional factors. These studies find that certain macroeconomic variables and arrangements of open macroeconomic policies, such as exchange rate regimes and capital account openness, are important in determining the sensitivity of countries' financial variables to policy changes in developed economies (Aizenman, Chinn, and Ito 2015; Ahmed and Zlate 2013). Some studies also emphasize global financial conditions by collapsing the Mundellian trilemma to a dilemma, suggesting that a flexible exchange rate does not necessarily give monetary policy autonomy (Rey 2015, 2016).

Determining which currencies will perform relatively worse during a crisis requires answering several questions. Which outcome variables should be focused on? Is percentage change in the exchange rate a robust indicator of the actual pressures faced by currency markets? Given an outcome variable, do economies with stronger macro fundamentals fare better? Or do factors such as exchange rate regime and capital account openness combined with the financial sector's overall size and exposure to the economy matter? And do interest rate differentials have a role to play when global risk increases? Answers to these questions are important for central banks to make evidence-based policy decisions.

This paper assesses these questions using a measure of exchange market pressure, and by distinguishing between pressure revealed in currency movements and pressure absorbed through reserve changes. We consider the role of macroeconomic fundamentals, short-term financial exposure, and portfolio rebalancing by foreign investors in determining the size and direction of exchange market pressure in developing and emerging economies facing a monetary policy shock. In doing this, we shed useful light on the role of policy choices - the exchange rate regime and capital account openness - in shaping desired outcomes.

The paper contributes to the literature in three ways. First, we assess the impact of the taper announcement on not only exchange rate movements but also on exchange market pressure, using a measure that is suitable for cross-country analysis. Second, we do this analysis on a mix of developing and emerging economies using the classification from the International Monetary Fund (IMF), whereas previous analyses have used Organisation for Economic Co-operation and Development countries or just emerging market economies. Given the significantly different impact on advanced and 
developing economies, a pooled analysis could give biased results. And third, we evaluate the significance of macroeconomic fundamentals, interest rate differentials, financial sector exposure to short-term flows, and policy choices, such as the exchange rate regime and capital account openness, to determine exchange market performance. Here, we consider de facto indicators of exchange rate regime and capital account openness, since legal restrictions might not capture the true extent of exchange rate intervention or cross-border flows. We also look beyond statistical significance to evaluate the relative importance of these factors.

Our results highlight the significance of financial integration on a country's exchange market performance during a financial shock. They also distinguish between the depreciation effects of short-term exposure to currency volatility from the appreciation effects of an open capital account during a financial shock. This is in addition to the stronger depreciation pressures that a flexible currency would face.

\section{DATA AND METHODOLOGY}

\section{A. Data}

The complete dataset consists of 93 economies belonging to the set of emerging and developing economies, as classified by the IMF. The Appendix lists the economies used in the analysis. Since the date of the taper announcement was on 22 May 2013, we take as our dependent variable exchange market pressure from May 2013 to August 2013. The monthly data for exchange market pressure is from Desai et al. (2017). To deal with the problem of endogeneity in the regression, we use data in the year preceding the tantrum period for the explanatory and control variables.

We consider the interest rate differential - that is, the gap between domestic and US interest rates-as an explanatory variable. The differential represents the relative attractiveness of domestic versus foreign assets and so affects the direction of short-term capital flows. We use the average of the 3-month Treasury bill rate as the short-term interest rate from April 2012 to April 2013.

The indicators representing macroeconomic health are the annual consumer price inflation rate averaged over 2010-2012, current account balance as a percentage of gross domestic product (GDP) in 2012, fiscal deficit as a percentage of GDP, and gross public debt as a percentage of GDP in 2012. All are considered as explanatory variables. Data for annual consumer price inflation rate are from the World Bank's World Development Indicators (WDI) Database. Gross public debt as a percentage of GDP is from the IMF's Historical Public Debt Database, and fiscal deficit as a percentage of GDP is from the IMF's World Economic Outlook Database.

To account for trade-related channels, which could represent the vulnerability of the economy to external shocks, we include current account balances as a percentage of GDP and trade openness for 2012. 'Both variables are from the WDI.

\footnotetext{
1 Trade openness is the total sum of exports and imports as a percentage of GDP.
} 
We include economic size, measured by real GDP per capita in 2012 using WDI data, and the de facto capital openness indicator as controls. The variables used to account for the financial size of an economy as well as its exposure to currency shocks are average total private external financing during 2010-2012, sourced from the IMF's Global Financial Stability Report, and the stock of portfolio liabilities and portfolio equity liabilities in 2012, sourced from Lane and Milesi-Feretti (2017). ${ }^{2}$ We construct the de facto capital account openness indicator, as defined in Lane and Milesi-Feretti (2007). ${ }^{3}$ Table 8 shows the summary statistics of the indicators.

We also include the following categorical variables as controls: (i) whether the economy is an emerging market as indicted by its inclusion in the MSCl Emerging Markets Index, (ii) whether it is a global financial center, and (iii) exchange rate regime indicator. ${ }^{4}$ Emerging markets on the index experience bidirectional capital flows, and might be more susceptible to global shocks, given the criteria for market accessibility to investors. The data for global financial centers is from China Development Institute (2018). The exchange rate regime indicator is from the dataset in Ilzetzki, Reinhart, and Rogoff (2017).

\section{B. Methodology}

To evaluate the significant determinants of exchange market pressure during the taper tantrum, we follow Ahmed, Coulibaly and Zlate (2017) to do a cross-sectional regression across economies with the following specification:

$$
E M P_{i}=\beta_{0}+\sum_{j=1}^{k} \beta_{i} X_{i j}+\epsilon_{i}
$$

We start with a set of $k$ explanatory variables $X_{j}$, and add others to determine their relation to exchange market pressure, $E M P_{i}$ in each country $i$. Dummy variables are included to account for the status of an economy as an emerging market; and as a global financial center, to account for any structural difference in the exchange market performance of the economies. We report coefficients with robust standard errors, followed by coefficients estimated from the standardized regression technique to ascertain the relative importance of significance variables. We then perform a robust regression to account for outliers or observations that do not follow the general structure of the dataset. We use a robust regression estimator, called MM-estimator, as described in Koller and Stahel (2011), which by default uses a bi-square descending score function and returns a highly robust and efficient estimator (with 50\% breakdown and 95\% asymptotic efficiency for normal errors).

\footnotetext{
Total external financing consists of the sum of private inflows in equities, bonds, and debt.

Capital account openness is the ratio of the sum of the stock of total external assets and liabilities to GDP.

4 The MSCl Emerging Markets Index consists of 24 economies representing 10\% of world market capitalization. They are: Brazil; India; Chile; Colombia; the Czech Republic; Egypt; Greece; Hungary; Indonesia; Mexico; Pakistan; the People's Republic of China; Peru; the Philippines; Poland; Qatar; Malaysia; the Republic of Korea; the Russian Federation; South Africa; Taipei,China; Thailand; Turkey; and the United Arab Emirates.
} 
To check for the robustness of the results for alternative specifications, we do the regressions with other measures of exchange market pressure as well as alternative exchange rate regime schemes. We also do the analysis for the first quantitative easing period to assess whether the main determinants of exchange market pressure differ in the case of appreciation shocks in relation to depreciation shocks.

\section{RESULTS}

To identify the importance of macroeconomic and financial fundamentals on the exchange market performance of emerging and developing economies, it is essential to first analyze the behavior and determinants of exchange rate movements. Figure 2 shows the sharp depreciation experienced by these economies across all regions after the taper announcement. We complement this analysis with the results in the following section to understand the factors determining an economy's exchange rate movements.

As described in the Motivation and Questions section, changes in exchange rates do not encompass the pressure experienced by currencies. We give the results for the estimation of determinants of exchange market pressure during the taper tantrum in a later section.

\section{A. Determinants of Exchange Rate Changes}

Table 1 shows the estimation results for the determinants of percentage change in exchange rates during the taper talk; in other words, a depreciation shock. Specifications 1-6 of Table 1 show the estimated effects of macroeconomic fundamentals on exchange rate movements from May to August 2013. We find that the interest rate differential is not significant in explaining the percentage change in exchange rates in developing and emerging economies. None of the macroeconomic fundamentals are significant in explaining movements in exchange rates. We find that after accounting for macroeconomic fundamentals, economies in the MSCI Emerging Market Index experienced 5\%-6\% higher depreciation than other economies in the sample.

To evaluate the impact of external fundamentals, we estimate the effects of the current account balance (as a percentage of GDP), trade openness, the size of total external private financing, and de facto capital account openness on the percent change in the exchange rate. We find that apart from capital account openness and total external private financing, none of the other variables explain the heterogeneity in exchange rate movements across economies. We observe this across specifications 7-11 in Table 1, where capital account openness is not only significant but also has a negative effect, implying that economies with higher capital account openness experienced lesser depreciation during the taper tantrum. We also find that economies with higher levels of private external financing experienced sharper depreciation, possibly because of the vulnerability of external borrowings to currency shocks.

Our results also show that economies that were global financial centers also experienced larger depreciation. We also observe significance in the exchange rate variable. Our reference level for the exchange rate regime variable is a hard peg. Our results in Table 1 show that an economy with an intermediate exchange rate regime experienced significantly greater depreciation than hard-peg currencies. 
Financial Shocks and Exchange Market Pressure | 11

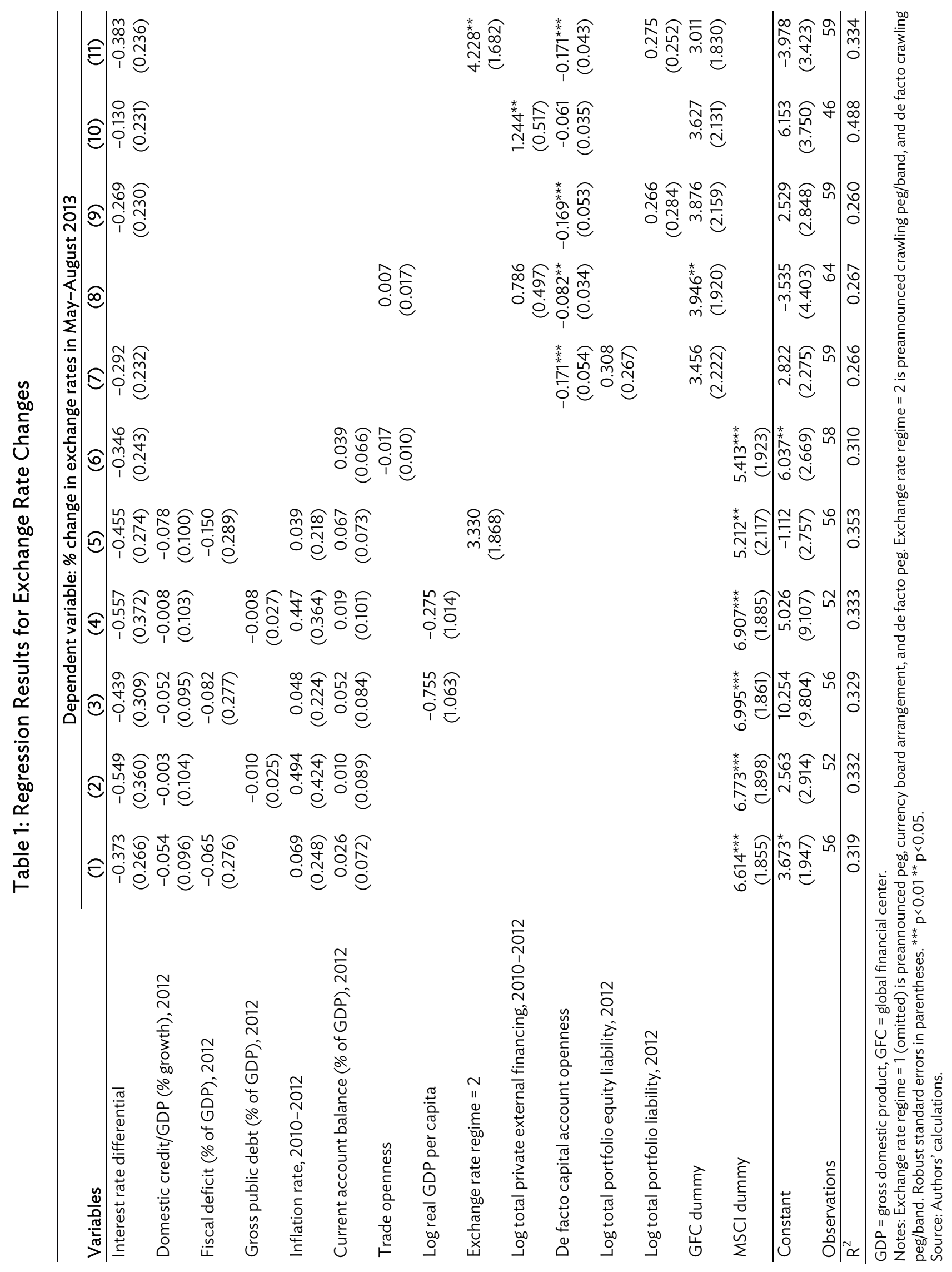




\section{B. Determinants of Exchange Market Pressure}

Our primary dependent variable is quarterly exchange market pressure from May to August $2013 .^{5}$ We look at various variables that might have affected exchange market pressure across all economies included in our sample during the taper tantrum. Table 2 shows the results of the estimation procedure, which enable us to answer the questions asked in the Motivation and Questions section.

Specifications 1-6 of Table 2 show the estimated effects of macroeconomic fundamentals on the exchange market pressure from May to August 2013. Across all specifications, we find the interest rate differential has no significant effect on exchange market pressure for emerging and developing economies. Controlling for real GDP per capita and exchange rate regimes, we find that none of the macroeconomic fundamentals are significant in explaining exchange market pressure. Our results also imply that the depreciation pressure was stronger for economies in the MSCI Emerging Markets Index than other developing and emerging economies, by $8 \%-9 \%$.

We find that both trade openness and total external financing have a positive and significant impact on exchange market pressure, implying that an economy with a higher proportion of trade relative to GDP and a higher level of private external financing faced greater depreciation pressures. A higher proportion of trade relative to GDP, as well as larger external financing increased an economy's exposure to external shocks, contributing to stronger depreciation pressures in the face of a financial shock.

$5 \quad E M P_{\text {May-August } 2013}=\sum_{i=0}^{3} E M P_{t+1}$. 
Financial Shocks and Exchange Market Pressure | 13

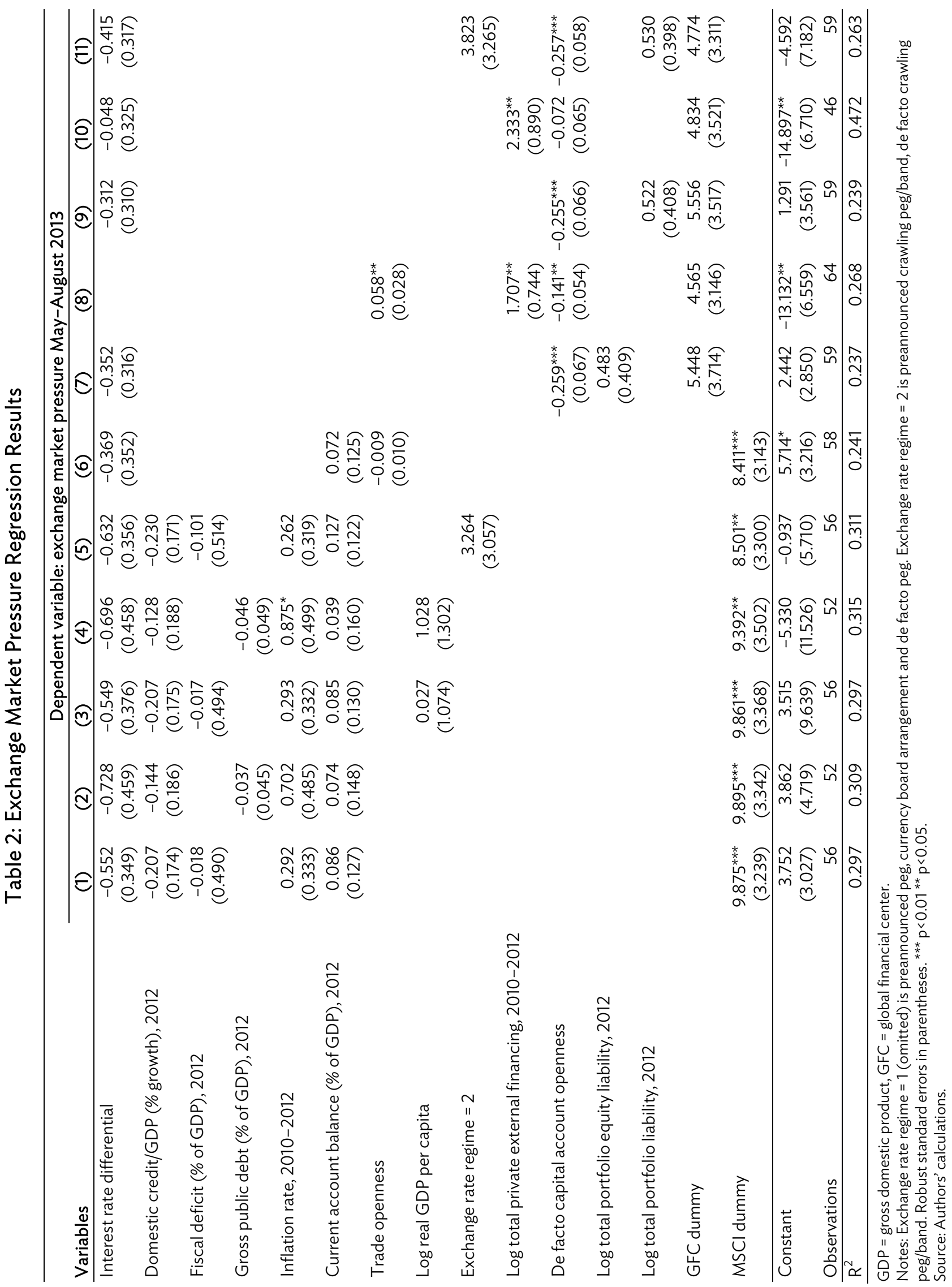


Specifications 7-11 assess the impact of size and extent of integration of the financial economy. Here, we see that de facto capital account openness has a negative and significant effect. This implies that countries with more open and globally integrated financial markets would have faced weaker depreciation pressure. This might be because economies that are more open and integrated with the global financial system are able to diversify the risk. The depreciation effect of total private external financing indicates the higher vulnerability of domestic borrowers who rely on external financing. Financial shocks can not only cause volatility in these flows but also affect channels of credit for these borrowers. ${ }^{6}$

In addition to statistical significance, we look at the relative strength of possible determinants of exchange market pressure through standardized regression coefficients (Table 3 ). We find that most variables with the highest magnitude of coefficients are also the significant variables, as reported in Table 2. Specification 8 in Table 3 shows that although capital account openness is a significant determinant, in the face of a financial shock, short-term private external flows are a stronger factor affecting the extent of exchange market pressure experienced by an economy. The vulnerabilities of the financial sector intensify the effects of a depreciation shock, and institutional factors, such as capital account openness, can to some extent dampen this effect.

On performing a robust regression, we find that trade openness loses its significance, whereas the exchange rate regime variable becomes significant with a depreciation effect (Table 4). This implies that compared with a hard-peg currency, an intermediate regime faces significantly higher depreciation pressure.

Our results support the view that country-specific institutional factors, such as exchange rate regime and de facto capital account openness, significantly affect exchange market pressure, although in different directions. Further, an economy with higher average levels of private external financing would face stronger depreciation pressures because of the higher exposure of its financial sector to currency shocks.

6 An important difference between analyses of exchange market pressure and percentage change in exchange rates is the size of the estimated coefficients of the determinants. We find the effects of both capital account openness and total private external financing are stronger on exchange market pressure than exchange rate movements. Similarly, economies in the MSCl Emerging Markets Index faced stronger depreciation pressures than the realized depreciation. This further reflects how merely assessing the impact of macroeconomic and financial variables on changes in exchange rates can understate the effect of these variables. 


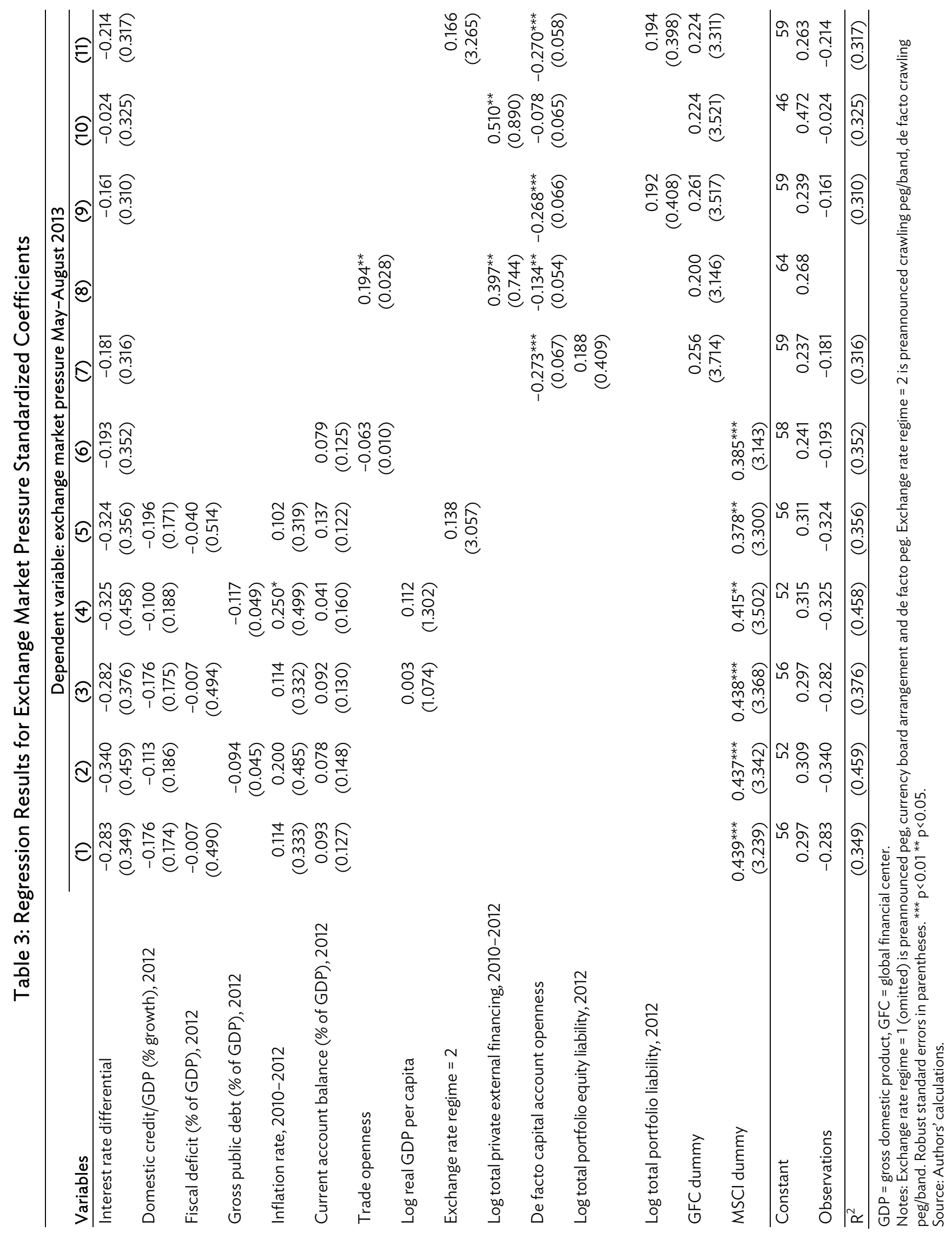




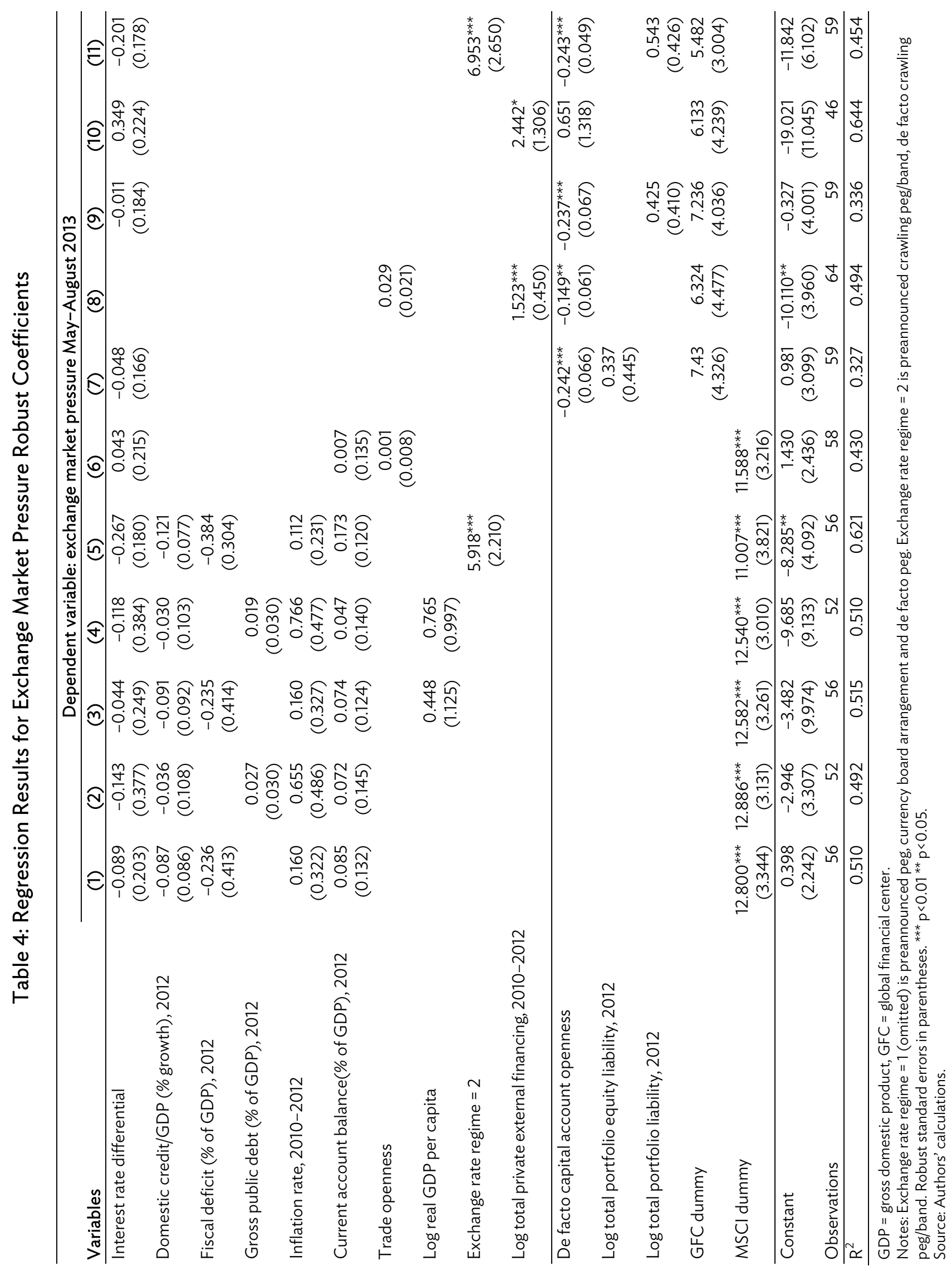




\section{ROBUSTNESS CHECKS}

We test to check whether our results are robust to the different variables used to indicate exchange rate regimes, alternative metrics of exchange market pressure, and whether the determinants of exchange market pressure differ while assessing an event of appreciation shock, such as QE-1.

\section{A. Alternative Measures of Exchange Rate Regimes}

We use the exchange rate stability index in Aizenman, Chinn, and Ito (2010) to assess whether our results are robust to alternative measures of exchange rate regime. The results in Table 5 show that the results in the following section are robust to other measures of an exchange rate regime.

Table 5: Alternative Measures of Exchange Rate Regimes Robust Coefficients

\begin{tabular}{|c|c|c|c|c|}
\hline \multirow[b]{2}{*}{ Variables } & \multicolumn{4}{|c|}{ Dependent Variable: Exchange Market Pressure May-August 2013} \\
\hline & m5_8_emp & m5_8_emp & m5_8_emp & m5_8_emp \\
\hline Interest rate differential & $\begin{array}{c}-0.267 \\
(0.180)\end{array}$ & $\begin{array}{r}-0.185 \\
(0.166)\end{array}$ & $\begin{array}{l}-0.201 \\
(0.178)\end{array}$ & $\begin{array}{c}-0.051 \\
(0.182)\end{array}$ \\
\hline Fiscal deficit (\% of GDP), 2012 & $\begin{array}{r}-0.384 \\
(0.304)\end{array}$ & $\begin{array}{r}-0.201 \\
(0.337)\end{array}$ & & \\
\hline Current account balance (\% of GDP), 2012 & $\begin{array}{r}0.173 \\
(0.120)\end{array}$ & $\begin{array}{r}0.154 \\
(0.136)\end{array}$ & & \\
\hline Domestic credit/GDP (\% growth), 2012 & $\begin{array}{r}-0.121 \\
(0.077)\end{array}$ & $\begin{array}{c}-0.168^{* *} \\
(0.084)\end{array}$ & & \\
\hline Inflation rate, $2010-2012$ & $\begin{array}{r}0.112 \\
(0.231)\end{array}$ & $\begin{array}{r}0.325 \\
(0.272)\end{array}$ & & \\
\hline Exchange rate regime $=2$ & $\begin{array}{c}5.918^{* * *} \\
(2.210)\end{array}$ & & $\begin{array}{c}6.953^{* * *} \\
(2.650)\end{array}$ & \\
\hline Exchange rate stability index & & $\begin{array}{c}-7.891^{* *} \\
(3.386)\end{array}$ & & $\begin{array}{r}-7.813^{* * *} \\
(2.896)\end{array}$ \\
\hline De facto capital account openness & & & $\begin{array}{r}-0.243^{* * *} \\
(0.049)\end{array}$ & $\begin{array}{r}-0.230^{* * *} \\
(0.049)\end{array}$ \\
\hline Log total portfolio liability, 2012 & & & $\begin{array}{r}0.543 \\
(0.426)\end{array}$ & $\begin{array}{r}0.369 \\
(0.396)\end{array}$ \\
\hline GFC dummy & & & $\begin{array}{c}5.482^{*} \\
(3.004)\end{array}$ & $\begin{array}{c}5.988^{*} \\
(3.468)\end{array}$ \\
\hline MSCI dummy & $\begin{array}{c}11.007^{* * *} \\
(3.821)\end{array}$ & $\begin{array}{r}10.432^{* * *} \\
(3.826)\end{array}$ & & \\
\hline Constant & $\begin{array}{c}-8.285^{* *} \\
(4.092)\end{array}$ & $\begin{array}{l}5.178^{* *} \\
(2.534)\end{array}$ & $\begin{array}{r}-11.842^{*} \\
(6.102)\end{array}$ & $\begin{array}{r}5.010 \\
(4.131)\end{array}$ \\
\hline Observations & 56 & 55 & 59 & 58 \\
\hline $\mathrm{R}^{2}$ & 0.621 & 0.587 & 0.454 & 0.399 \\
\hline
\end{tabular}

GDP = gross domestic product, GFC = global financial center .

Notes: Robust standard errors in parentheses. Anchor currencies and exchange rate arrangements for 194 countries from 1946 to 2016 are defined in Ilzetzki, Ethan, Carmen M. Reinhart, and Kenneth S. Rogoff. 2017. "Exchange Arrangements Entering the 21st Century: Which Anchor Will Hold?” NBER Working Paper No. 23134. Cambridge, MA: National Bureau of Economic Research. Their methodology to classify exchange rate regimes involves measuring exchange rate movements against the anchor currency for a specific window of time. A new measure of exchange rate stability is defined in Aizenman, Joshua, Menzie D. Chinn, and Hiro Ito. 2010. "The Emerging Global Financial Architecture: Tracing and Evaluating the New Patterns of the Trilemma's Configurations." Journal of International Money and Finance 29 (4): 615-41. The new measure is part of their trilemma indices, where higher index values imply greater stability of the exchange rate against an identified base country. ${ }^{* *} p<0.01^{* *} p<0.05^{*} p<0.1$.

Source: Authors' calculations. 


\section{B. Determinants of Exchange Market Pressure during Appreciation Pressures}

We include the same variables and specifications in Table 4 for the year 2007 to assess whether economies respond differently to depreciation and appreciation pressures. The dependent variable is the exchange market pressure from March to June 2009.

The results in Table 6 show that, contrary to those in Table 4, gross public debt had a significant impact on exchange market pressure experienced after the announcement of QE-1. Economies with high gross public debt as a percentage of GDP experienced weaker appreciation pressures than those with low gross public debt (higher public debt can indicate instability in the political economy). Trade openness and total external private financing, however, did not have a significant impact and $\mathrm{MSCl}$ Emerging Markets Index economies experienced significantly stronger appreciation pressure than other emerging and developing economies. We also find evidence for de facto capital account openness having a significant appreciation effect, similar to the results in Table 4.

In stark contrast to Table 4, the stock of total portfolio liabilities and total equity portfolio liabilities had a significant and negative impact. Economies with a larger stock of portfolio liabilities experienced stronger appreciation pressures, potentially because they are a signal for investors that such economies have lesser inflow restrictions, capacity, and the institutional wherewithal to absorb larger portfolio inflows.

\section{Alternative Exchange Market Pressure Measures}

To check the robustness of our results for determinants of exchange market pressure during the taper tantrum, we do the analysis with the exchange market pressure metric in Aizenman and Hutchison (2012), with the components of the metric weighted by their respective standard deviations. We take an average of the metric from May to August 2013 (Table 7).

Similar to our results in Table 2, we find that an increase in de facto capital account openness is associated with appreciation pressures on the domestic currency, and trade openness has a significant depreciation effect. We also see similar impacts of financial variables and exchange rate regime. 
Financial Shocks and Exchange Market Pressure | 19

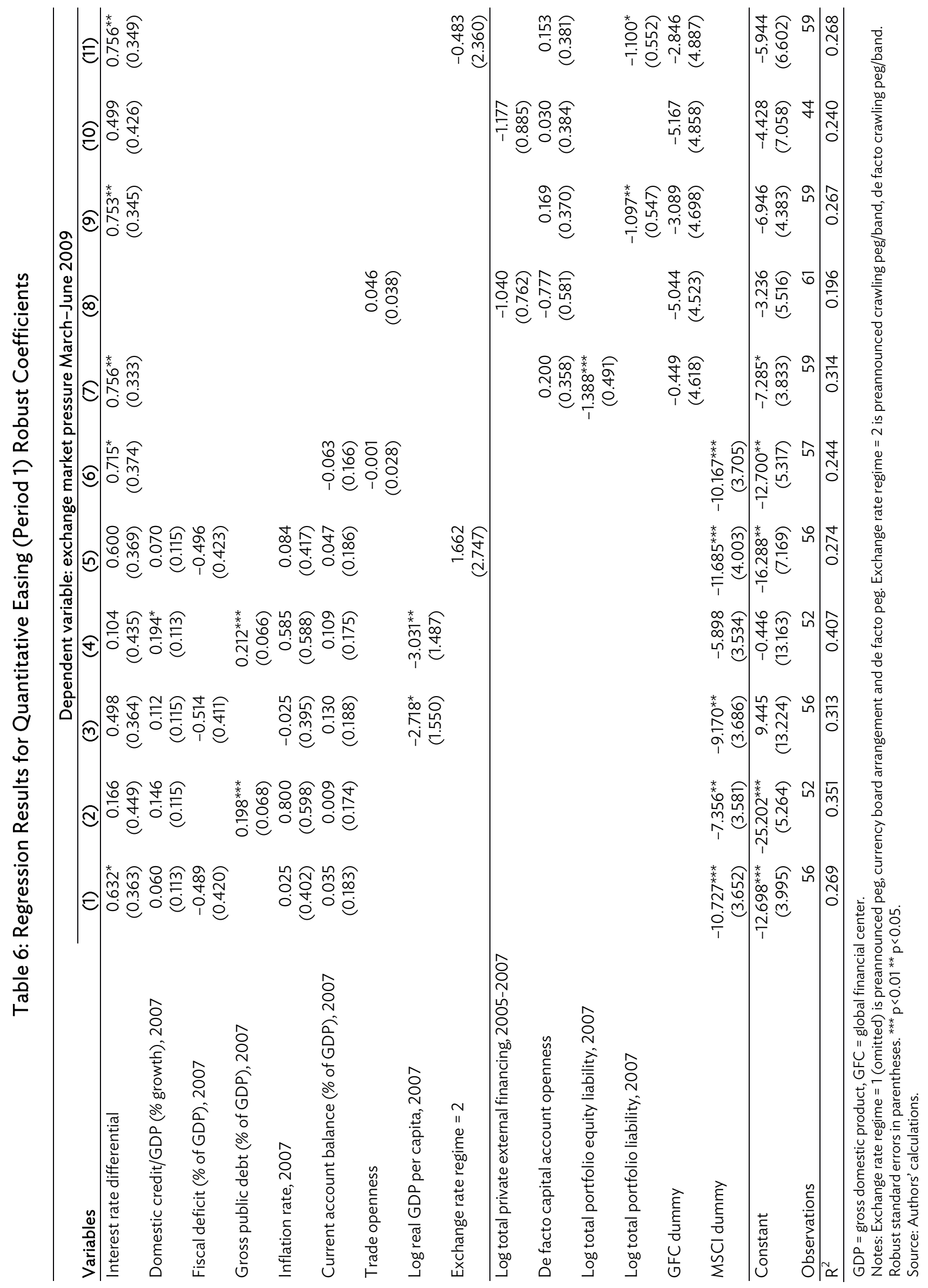




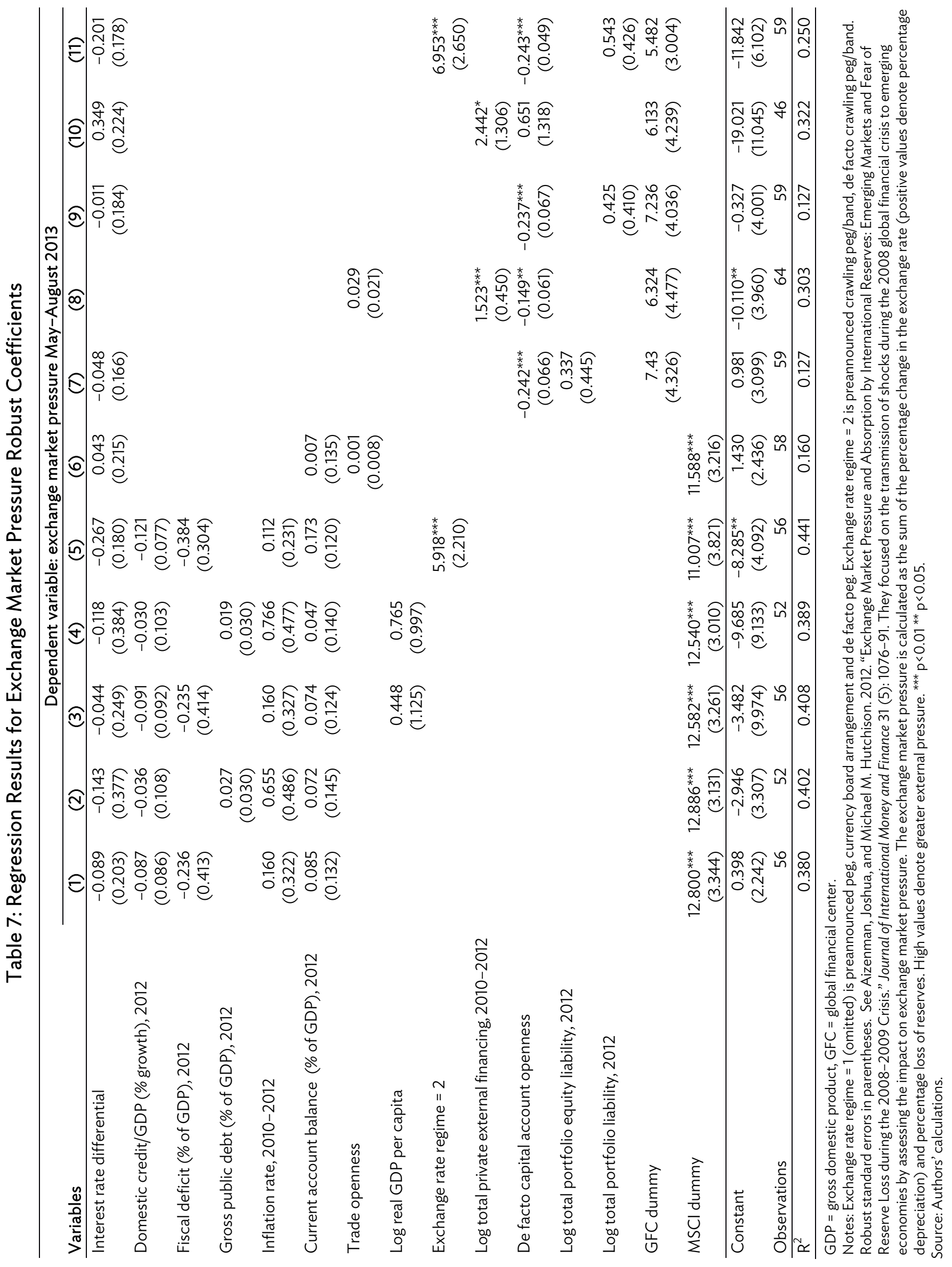


Table 8. Summary Statistics

\begin{tabular}{|c|c|c|c|c|c|c|}
\hline Item & $\mathrm{N}$ & Mean & SD & Min & $\operatorname{Max}$ & Source \\
\hline $\begin{array}{l}\text { Exchange market pressure, } \\
\text { (May-Aug 2013) }\end{array}$ & 89 & 5.2 & 12.2 & -27.5 & 79.0 & Patnaik et al $(2017)^{a}$ \\
\hline $\begin{array}{l}\text { Exchange rate change, } \\
\text { (May-Aug 2013) }\end{array}$ & 90 & 3.3 & 5.8 & -19.6 & 20.2 & Thomson Reuters Datastream \\
\hline $\begin{array}{l}\text { Interest rate differential } \\
\text { (April 2012-April 2013) }\end{array}$ & 59 & 6.5 & 5.1 & 0.0 & 22.2 & Thomson Reuters Datastream \\
\hline $\begin{array}{l}\text { Domestic credit/GDP (\% growth), } \\
2012\end{array}$ & 87 & 3.5 & 12.1 & -44.3 & 38.0 & WB, WDI Database \\
\hline Fiscal deficit (\% of GDP), 2012 & 92 & -2.1 & 5.4 & -15.7 & 28.6 & IMF, World Economic Outlook Database \\
\hline $\begin{array}{l}\text { Gross public debt (\% of GDP), } \\
2012\end{array}$ & 82 & 43.6 & 27.6 & 0.6 & 147.9 & IMF, Historical Public Debt Database \\
\hline Inflation rate, $2010-2012$ & 92 & 6.9 & 5.2 & 0.9 & 40.1 & WB, WDI Database \\
\hline $\begin{array}{l}\text { Current account balance } \\
\text { (\% of GDP), } 2012\end{array}$ & 89 & -4.8 & 11.2 & -46.7 & 29.8 & WB, WDI Database \\
\hline Trade openness, 2012 & 87 & 91.8 & 58.1 & 22.4 & 430.6 & WB, WDI Database \\
\hline Log real GDP per capita, 2012 & 90 & 8.0 & 1.1 & 5.8 & 10.8 & WB WDI Database \\
\hline Exchange rate regime, 2012 & 93 & 1.7 & 0.5 & 1.0 & 3.0 & Ilzetzki et al. (2017) \\
\hline $\begin{array}{l}\text { Log total private external } \\
\text { financing, 2010-2012 }\end{array}$ & 68 & 6.9 & 2.4 & 0.2 & 11.5 & IMF, Global Financial Stability Report \\
\hline $\begin{array}{l}\text { De facto capital account } \\
\text { openness }\end{array}$ & 92 & 2.7 & 8.4 & 0.4 & 77.0 & $\begin{array}{l}\text { Author's calculation based on Lane and } \\
\text { Milesi-Feretti }(2007)^{c}\end{array}$ \\
\hline $\begin{array}{l}\text { Log total portfolio equity liability, } \\
2012\end{array}$ & 92 & 5.5 & 3.9 & 0.0 & 13.1 & Lane and Milesi-Feretti $(2017)^{d}$ \\
\hline Log total portfolio liability, 2012 & 92 & 6.9 & 3.7 & 0.0 & 13.3 & Lane and Milesi-Feretti (2017) ${ }^{\mathrm{d}}$ \\
\hline
\end{tabular}

$\mathrm{GDP}=$ gross domestic product, $\mathrm{IMF}=$ International Monetary Fund, $\mathrm{SD}=$ standard deviation, $\mathrm{WB}=$ World Bank, WDI = World Development Indicators .

a Patnaik, Ila, Joshua Felman, and Ajay Shah. 2017. "An Exchange Market Pressure Measure for Cross Country Analysis." Journal of International Money and Finance 73 (Part A): 62-77.

'Ilzetzki, Ethan, Carmen M. Reinhart, and Kenneth S. Rogoff. 2017. "Exchange Arrangements Entering the 21st Century: Which Anchor Will Hold?" NBER Working Paper No. 23134. Cambridge, MA: National Bureau of Economic Research.

'Lane, Philip R., and Gian Maria Milesi-Feretti. 2007. "The External Wealth of Nations Mark II: Revised and Extended Estimates of Foreign Assets and Liabilities, 1970-2004.” Journal of International Economics 73 (2): 223-50.

'Lane, Philip R., and Gian Maria Milesi-Feretti. 2017. "International Financial Integration in the Aftermath of the Global Financial Crisis.” IMF Working Paper No. 115. Washington, DC: International Monetary Fund.

\section{CONCLUSION}

The taper tantrum affected emerging and developing economies much harder than developed economies. Market expectations of a rapid tightening, despite the communicated stance of the Federal Reserve to taper quantitative easing, led to a massive sell-off in emerging market assets. The resultant sharp currency depreciation had differential magnitudes and durations across economies.

Due to weak macroeconomic fundamentals, certain economies were more fragile than others. In this paper, we highlight the importance of macroeconomic fundamentals, financial sector characteristics, exchange rate regimes and capital account openness. We find little evidence for the significance of macroeconomic fundamentals. Country-specific factors that define the exposure of financial sectors to currency volatility in the short-term are found to have a significant effect on 
exchange market pressure, whereas de facto capital account openness attenuates the effect of a depreciation shock. The effect of private external financing is relatively stronger as well. We also find that countries with flexible currencies faced steep nominal depreciation along with stronger depreciation pressures.

Contrary to what we observed for the taper tantrum, the differential impact on exchange market pressure during the QE-1 episode was driven by both financial sector variables and macroeconomic fundamentals. We also find that economies listed on the $\mathrm{MSCl}$ Emerging Markets Index faced much stronger depreciation pressures, possibly because of the bidirectional nature of their flows. This result is supported by our analysis of exchange market pressure after the announcement of QE-1, where we see these economies facing significantly stronger appreciation effects. For providing additional support for the role of capital account openness in determining exchange market pressure, we find capital account openness to have an appreciation effect in this case as well.

Our results hold immense significance for explaining the exchange market events of the recent past. Aside from a few exceptions, emerging economies greatly improved their macroeconomic fundamentals after the taper tantrum. Since May 2018, however, many of these economies experienced massive equity outflows, resulting in steep currency depreciation. Flexible currencies also faced depreciation pressures, and economies with a greater exposure to external borrowing in the recent past experienced liquidity crises. But policies that increase de facto capital account openness can absorb the depreciation pressure to some extent. Our results are therefore relevant for policy decisions. 


\section{APPENDIX: DEVELOPED AND EMERGING ECONOMIES USED IN THE SAMPLE}

\begin{tabular}{|c|c|c|}
\hline Economies & $\mathrm{MSCl}$ Classification & GFC Dummy \\
\hline \multicolumn{3}{|l|}{ Africa } \\
\hline Angola & 0 & 0 \\
\hline Botswana & 0 & 0 \\
\hline Congo, Democratic Republic of & 0 & 0 \\
\hline Central African Republic & 0 & 0 \\
\hline Côte d'Ivoire & 0 & 0 \\
\hline Djibouti & 0 & 0 \\
\hline Algeria & 0 & 0 \\
\hline Egypt & 1 & 0 \\
\hline Eritrea & 0 & 0 \\
\hline Gambia, The & 0 & 0 \\
\hline Guinea & 0 & 0 \\
\hline Kenya & 0 & 0 \\
\hline Comoros & 0 & 0 \\
\hline Liberia & 0 & 0 \\
\hline Libya & 0 & 0 \\
\hline Morocco & 0 & 1 \\
\hline Madagascar & 0 & 0 \\
\hline Mauritania & 0 & 0 \\
\hline Mauritius & 0 & 1 \\
\hline Malawi & 0 & 0 \\
\hline Mozambique & 0 & 0 \\
\hline Rwanda & 0 & 0 \\
\hline Sierra Leone & 0 & 0 \\
\hline Swaziland & 0 & 0 \\
\hline Tanzania & 0 & 0 \\
\hline Uganda & 0 & 0 \\
\hline South Africa & 1 & 1 \\
\hline Zambia & 0 & 0 \\
\hline \multicolumn{3}{|l|}{ Asia } \\
\hline Armenia & 0 & 0 \\
\hline Azerbaijan & 0 & 1 \\
\hline Bangladesh & 0 & 0 \\
\hline Brunei Darussalam & 0 & 0 \\
\hline Bhutan & 0 & 0 \\
\hline
\end{tabular}




\begin{tabular}{|c|c|c|}
\hline Economies & $\mathrm{MSCl}$ Classification & GFC Dummy \\
\hline China, People's Republic of & 1 & 1 \\
\hline Georgia & 0 & 0 \\
\hline Hong Kong, China & 0 & 1 \\
\hline Indonesia & 1 & 1 \\
\hline India & 1 & 1 \\
\hline Kyrgyz Republic & 0 & 0 \\
\hline Cambodia & 0 & 0 \\
\hline Korea, Republic of & 1 & 1 \\
\hline Kazakhstan & 0 & 1 \\
\hline Lao People's Democratic Republic & 0 & 0 \\
\hline Sri Lanka & 0 & 0 \\
\hline Myanmar & 0 & 0 \\
\hline Mongolia & 0 & 0 \\
\hline Maldives & 0 & 0 \\
\hline Malaysia & 1 & 1 \\
\hline Nepal & 0 & 0 \\
\hline Philippines & 1 & 1 \\
\hline Pakistan & 1 & 0 \\
\hline Singapore & 0 & 1 \\
\hline Thailand & 1 & 1 \\
\hline Tajikistan & 0 & 0 \\
\hline Viet Nam & 0 & 0 \\
\hline \multicolumn{3}{|l|}{ Middle East } \\
\hline Iraq & 0 & 0 \\
\hline Jordan & 0 & 0 \\
\hline Lebanon & 0 & 0 \\
\hline Syrian Arab Republic & 0 & 0 \\
\hline Yemen & 0 & 0 \\
\hline \multicolumn{3}{|l|}{ Europe } \\
\hline Bosnia and Herzegovina & 0 & 0 \\
\hline Bulgaria & 0 & 0 \\
\hline Belarus & 0 & 0 \\
\hline Croatia & 0 & 0 \\
\hline Moldova & 0 & 0 \\
\hline Macedonia & 0 & 0 \\
\hline Romania & 0 & 0 \\
\hline Serbia & 0 & 0 \\
\hline
\end{tabular}




\begin{tabular}{|c|c|c|}
\hline Economies & MSCI Classification & GFC Dummy \\
\hline Russian Federation & 1 & 1 \\
\hline Turkey & 1 & 1 \\
\hline Ukraine & 0 & 0 \\
\hline \multicolumn{3}{|l|}{ Latin America } \\
\hline Argentina & 0 & 1 \\
\hline Bolivia & 0 & 0 \\
\hline Brazil & 1 & 1 \\
\hline Belize & 0 & 0 \\
\hline Colombia & 1 & 0 \\
\hline Costa Rica & 0 & 0 \\
\hline Dominican Republic & 0 & 0 \\
\hline Guatemala & 0 & 0 \\
\hline Guyana & 0 & 0 \\
\hline Honduras & 0 & 0 \\
\hline Haiti & 0 & 0 \\
\hline Jamaica & 0 & 0 \\
\hline Mexico & 1 & 1 \\
\hline Peru & 1 & 0 \\
\hline Suriname & 0 & 0 \\
\hline El Salvador & 0 & 0 \\
\hline Venezuela & 0 & 0 \\
\hline \multicolumn{3}{|l|}{ Pacific } \\
\hline Fiji & 0 & 0 \\
\hline Solomon Islands & 0 & 0 \\
\hline Tonga & 0 & 0 \\
\hline Vanuatu & 0 & 0 \\
\hline Samoa & 0 & 0 \\
\hline
\end{tabular}

GFC = global financial crisis, Lao PDR = Lao People's Democratic Republic.

Sources: China Development Institute. 2018. The Global Financial Centres Index 23. Shenzhen; and MSCI Country Classification Standard. 


\section{REFERENCES}

Ahmed, Shaghil, Brahima Coulibaly, and Andrei Zlate. 2017. "International Financial Spillovers to Emerging Market Economies: How Important Are Economic Fundamentals?" Journal of International Money and Finance 76: 133-52.

Ahmed, Shaghil, and Andrei Zlate. 2013. "Capital Flows to Emerging Market Economies: A Brave New World." Board of Governors of the Federal Reserve System International Finance Discussion Papers No. 1081. Washington, DC: Federal Reserve.

Aizenman, Joshua, and Mahir Binici. 2016. "Exchange Market Pressure in OECD and Emerging Economies: Domestic Vs. External Factors and Capital Flows in the Old and New Normal." Journal of International Money and Finance 66 (C): 65-87.

Aizenman, Joshua, Menzie Chinn, and Hiro Ito. 2010. "The Emerging Global Financial Architecture: Tracing and Evaluating the New Patterns of the Trilemma's Configurations." Journal of International Money and Finance 29 (4): 615-41.

2015. "Monetary Policy Spillovers and the Trilemma in the New Normal: Periphery Country Sensitivity to Core Country Conditions." NBER Working Paper No. 21128. Cambridge, MA: National Bureau of Economic Research.

Aizenman, Joshua, and Michael Hutchison. 2012. "Exchange Market Pressure and Absorption by International Reserves: Emerging Markets and Fear of Reserve Loss during the 2008-2009 Crisis." Journal of International Money and Finance 31 (5): 1076-91.

China Development Institute. 2018. "The Global Financial Centres Index 23.” Shenzhen.

Desai, Mohit, Ila Patnaik, Joshua Felman, and Ajay Shah. 2017. "A Cross-Country Exchange Market Pressure (EMP) Dataset.” Data in Brief 12 (June): 652-55.

Eichengreen, Barry, and Poonam Gupta. 2015. "Tapering Talk: The Impact of Expectations of Reduced Federal Reserve Security Purchases on Emerging Markets.” Emerging Markets Review 25 (C): 115.

Feldkircher, Martin, Roman Horvath, and Marek Rusnak. 2014. "Exchange Market Pressures during the Financial Crisis: A Bayesian Model Averaging Evidence." Journal of International Money and Finance 40: 21-41.

Frankel, Jeffrey, and George Saravelos. 2012. "Can Leading Indicators Assess Country Vulnerability? Evidence from 2008-09 Global Financial Crisis." Journal of International Economics 87 (2): 216-31.

Ilzetzki, Ethan, Carmen Reinhart, and Kenneth Rogoff. 2017. "Exchange Arrangements Entering the 21st Century: Which Anchor Will Hold?" NBER Working Paper No. 23134. Cambridge, MA: National Bureau of Economic Research.

Koller, Manuel, and Werner Stahel. 2011. "Sharpening Wald-Type Inference in Robust Regression for Small Samples." Computational Statistics and Data Analysis 55 (8): 2504-15. 
Lane, Philip R., and Gian Maria Milesi-Feretti. 2007. "The External Wealth of Nations Mark II: Revised and Extended Estimates of Foreign Assets and Liabilities, 1970-2004." Journal of International Economics 73 (2): 223-20.

- 2017. "International Financial Integration in the Aftermath of the Global Financial Crisis." IMF Working Paper No. 115. Washington, DC: International Monetary Fund.

Lim, Jamus Jerome, Sanket Mohapatra, and Marc Stocker. 2014. "Tinker, Taper, QE, Bye? The Effect of Quantitative Easing on Financial Flows to Developing Countries." Policy Research Working Paper No. 6820. Washington, DC: World Bank.

Patnaik, Ila, Joshua Felman, and Ajay Shah. 2017. "An Exchange Market Pressure Measure for Cross Country Analysis.” Journal of International Money and Finance 73 (Part A): 62-77.

Rey, Helene 2015. "Dilemma Not Trilemma: The Global Financial Cycle and Monetary Policy Independence." NBER Working Paper No. 21162. Cambridge, MA: National Bureau of Economic Research.

2016. "International Channels of Transmission of Monetary Policy and the Mundellian Trilemma." NBER Working Paper No. 21852. Cambridge, MA: National Bureau of Economic Research. 


\section{Financial Shocks and Exchange Market Pressure}

After a long period of low interest rates in the United States, tapering quantitative easing in May 2013 led to sizable inflow reversals and currency depreciation in emerging and developing economies. This paper provides evidence for the importance of capital account openness in buffering depreciation pressures during the taper tantrum episode and shows that exposure to external private financing and having a more flexible exchange rate regime led to higher depreciation pressures. Macroeconomic fundamentals, however, did not matter for exchange market pressure.

\section{About the Asian Development Bank}

ADB is committed to achieving a prosperous, inclusive, resilient, and sustainable Asia and the Pacific, while sustaining its efforts to eradicate extreme poverty. Established in 1966, it is owned by 68 members49 from the region. Its main instruments for helping its developing member countries are policy dialogue, loans, equity investments, guarantees, grants, and technical assistance. 